\title{
ОСОБЛИВОСТІ МЕЛАТОНІНУТВОРЮВАЛЬНОЇ ФУНКЦІЇ ЕПІФІЗУ ТА ДИСЛІПІДЕМІЇ У ХВОРИХ НА ХРОНІЧНУ ХВОРОБУ НИРОК 5 Д СТАДІЇ
}

\author{
${ }^{1}$ В.Є. КОНДРАТЮК, 1,2А.С. ПЕТРОВА, 1,2О.В. КАРПЕНКО, \\ ${ }_{1,2}^{1}$ C.М. ГРИГОР'ЄВА
}

${ }^{1}$ Національний медичний університет ім. О.О. Богомольця, м. Київ

${ }^{2}$ КНП «Київський міський центр нефрології та діалізу», м. Київ

Резюме.

\begin{abstract}
Мета дослідження: проаналізувати мелатонінутворювальну функцію епіфізу (МФЕ) та показники ліпідного обміну крові хворих на хронічну хворобу нирок (XXН) 5 Д стадії та визначати взаємозв'язок дисліпідемії з МФЕ.

Матеріал і методи: Обстежено 130 осіб (50 \% чоловіки) у віці 58,5 [43; 66] років, що знаходяться на постійному лікуванні гемодіалізом. Усім хворим проведені клініко-лабораторні дослідження: загальний та біохімічний аналізи крові 3 визначенням рівня холестерину та його фракцій, визначено денний та нічний рівень мелатоніну в слині методом імуноферментного аналізу, проведено вимірювання офісного артеріального тиску (АТ).
\end{abstract}

Результати та обговорення: Виявлено значну поширеність порушення МФЕ у хворих на XXН 5 Д стадії та його взаємозв'язок з ліпідним спектром крові. Визначено негативний кореляційний зв'язок нічного рівня мелатоніну з загальним холестерином (3X) $(r=-0,26 ; p<0,05)$, негативний кореляційний зв'язок з тригліцеридами (ТГ) $(r=-0,27 ; p<0,05)$ та позитивний кореляційний зв'язок з ліпопротеїдами високої щільності (ЛПВЩ) $(r=0,33 ; p<0,05)$. Отримано позитивний зв'язок ЛПВЩ та денного рівня мелатоніну $(r=0,27 ; p<0,05)$ За аналізом результатів дослідження ліпідного метаболізму у пацієнтів на гемодіалізі відзначена наявність підвищеної концентрації загального ЗХ, ТГ, фракцій ліпопротеїдів низької щільності (ЛПНЩ) та низький вміст ЛПВЩ. Хворі з порушеною МФЕ в порівнянні з групою II мають достовірно вищі рівні ЗХ, ТГ, ЛПНЩ та нижчі рівні ЛПВЩ.

Висновки: Для Хворих на XXН 5Д ст., що лікуються методом гемодіалізу, притаманні виражені порушення ліпідного обміну (58\%). У хворих на нирково - замісній терапії порушення ліпідного метаболізму асоційоване з мелатонінутворювальною функцією епіфізу, рівнями систолічного та діастолічного артеріального тиску, тривалістю артеріальної гіпертензії, рівнем гемоглобіну та тривалістю лікування гемодіалізу.

Ключові слова: хронічна хвороба нирок, гемодіаліз, мелатонін, мелатонінутворювальна функція епіфізу, дисліпідемія.

ВСТУП. Хронічна хвороба нирок (ХХН) є однією з найважливіших медико-соціальних проблем, адже спостерігається чітка тенденція до зростання осіб з даною патологією. Незважаючи на високий рівень надання лікувальної допомоги та удосконалення методів замісної ниркової терапії (ЗНТ), дотепер не забезпечується повна корекція гемодинамічних, гормональних та обмінних процесів, пов'язаних з втратою функції нирок. Останнім часом актуальнішим стає питання підвищення якості та тривалості життя даної категорії хворих [10].

Основною причиною смерті хворих на XXH $\epsilon$ серцево-судинні захворювання (ССЗ), частка яких складає більше 48\% від загальної структури летальності. Вже на ранніх стадіях XXН спостерігаються виражені зміни ліпідного профілю, що призводять до більш стрімкого розвитку атеросклерозу та ССЗ.

Наявність дисліпідемії $є$ ключовим фактором у розвитку та прогресуванні XXH і СС3. [3]. При XXH наявні всі основні фактори ризику розвитку атеросклерозу: диспротеїнемія, довготривала артеріальна гіпертензія, гіперпаратиреоїдизм, гіперінсулінемія, порушення толерантності до глюкози, гіпопротеїнемія, запалення, прискорення апоптозу та збільшення кількості вільних радикалів детермінує накопичення змінених ліпопоротеїдів та комплексів «ліпопротеїди-антитіло» в крові. У хворих з уремією факторами атерогене- 
зу є гіперактивація згортальної системи крові та пригнічення фібринолізу, використання ацетатного діалізату, перманентне використання гепарину, бета-адреноблокаторів та інш. [9]. Корекція дисліпідемії хворих на гемодіалізі є важливим питанням практики нефролога. Проте рекомендації KDIGO 2013 року по веденню хворих на XXH із дисліпідемією не рекомендують розпочинати лікування статинами пацієнтам на гемодіалізі, котрі не отримували їх до початку ЗНТ [5]. Тому актуальним $€$ пошук шляхів корекції дисліпідемії у хворих на XXH. У низці досліджень мелатонін демонструє антиоксидантну властивість у хворих з неалкогольною жировою хворобою печінки, інфаркті міокарда, артеріальній гіпертензії та при кардіотоксичних станах [2]. Цікавою та перспективною виявляється здатність мелатоніну зменшувати рівень загального холестерину, ТГ, лПНЩ, фактору некрозу пухлин (ФНП- $)$, стимулювати утворення глутатіону, що забезпечує протекцію ліпідів від окислення. Мелатонін впливає на метаболізм холестерину, модулюючи активність макрофагів та регулюючи секрецію цитокінів, зокрема ІЛ-2 [1, 4]. Разом з тим мелатонінут- ворювальна функція епіфізу (МФЕ) та її зв'язок 3 ліпідним спектром крові у гемодіалізних хворих залишається маловивченим питанням.

Матеріали та методи. 3 метою клінічної оцінки ліпідного спектру крові обстежено 130 пацієнтів (чоловіків - 65, жінок - 65) з ХХН 5Д стадії, які знаходилися на лікуванні гемодіалізом в умовах комунального некомерційного підприємства «Київський міський центр нефрології та діалізу». Усім обстеженим, окрім загальноприйнятих клініко-лабораторних 3 визначенням параметрів ліпідного спектру крові та інструментальних методів дослідження, проводилися визначення рівня мелатоніна в слині імуноферментним методом з використанням комерційного набору Human MS (Melatonin Sulfate) ELISA Kit, Elabscience. 3aбір проводили в денний та нічний час, при мінімальному освітленні $30 \mathrm{~lx}$. Проводилося офісне вимірювання артеріального тиску (АТ) з аналізом систолічного АТ (САТ), діастолічного АТ (ДАТ) та пульсового АТ (ПАТ).

Демографічні дані та клінічна характеристика включених у дослідження хворих, продемонстровані в таблиці 1.

\section{Клініко - демографічна характеристика пацієнтів}

Таблиця 1

\begin{tabular}{|l|c|}
\hline \multicolumn{1}{|c|}{ Показник } & Пацієнти (n=130) \\
\hline Стать ч, n/\% & $65(50 \%)$ \\
\hline Вік, роки & $58,5[43 ; 66]$ \\
\hline Тривалість лікування ГД, роки & $11[6 ; 13]$ \\
\hline еКt/V & $1,28[1,24 ; 1,32]$ \\
\hline IMT, кг/м² & $21,3[20,1 ; 22,3]$ \\
\hline Окружність талії, см & $88[79 ; 92]$ \\
\hline «уха» вага, кг & $65[56 ; 75]$ \\
\hline Міждіалізна прибавка ваги, кг & $3[2,7 ; 3,2]$ \\
\hline Середній САТ, мм рт ст & $150[140 ; 160]$ \\
\hline Середній ДАТ, мм рт ст & $90[80 ; 92]$ \\
\hline Тривалість артеріальної гіпертензії, р. & $11[6 ; 13]$ \\
\hline Гемоглобін, г/л & $85[77 ; 92]$ \\
\hline Сатурація трансферину, \% & $32,6[22,8 ; 36,9]$ \\
\hline СРБ (г/л) & $19[12 ; 26]$ \\
\hline Сечова кислота, ммоль/л & $398[381 ; 423]$ \\
\hline Загальний білок, г/л & $64[60 ; 66]$ \\
\hline Альбумін (г/л) & $35[32 ; 36]$ \\
\hline іПТГ (пг/мл) & $530[313 ; 614]$ \\
\hline Р (ммоль/л) & $1,88[1,55 ; 2,03]$ \\
\hline Са2+ (ммоль/л) & $2,12[1,98 ; 2,25]$ \\
\hline Калій до діалізу (ммоль/л) & $5,1[4,8 ; 5,4]$ \\
\hline
\end{tabular}

Скорочення: ІМТ - індекс маси тіла, САТ - систолічний артеріальний тиск, ДАТ - діастолічний артеріальний тиск, СРБ - С-реактивний білок, Р - фосфор, Са2+ - кальцій, іПТГ - інтактний паратгормон.

Під час виконання роботи дотримані принципи біоетики, законодавчих норм та вимог щодо проведення біомедичних досліджень.

Статистичну обробку результатів проведено за допомогою програми Microsoft Office Excel
2010 та IBM Statistics Spss 22. Неперервні дані представлені медіаною та міжквартильним розмахом (Ме [Q25 - Q75]), категоріальні - виражені у відсотках (\%). Для порівняння нормально розподілених даних використовували крите- 
рій Ст'юдента (kS), за невідповідності закону нормального розподілу застосовували непараметричний (U-критерій) Манна-Уітні. Кореляційний зв'язок визначали за методами Пірсона (r) та Спірмена (rs) залежно від розподілу показників.
Результати дослідження та їх обговорення. Серед основних причин, що призвели до розвитку термінальної ниркової недостатності в обстежуваних пацієнтів превалювали гломерулонефрит та гіпертензивна нефропатія (кожний третій пацієнт), найменше хворих визначалось з сечокам'яною хворобою та полікистозом нирок (рис.1).

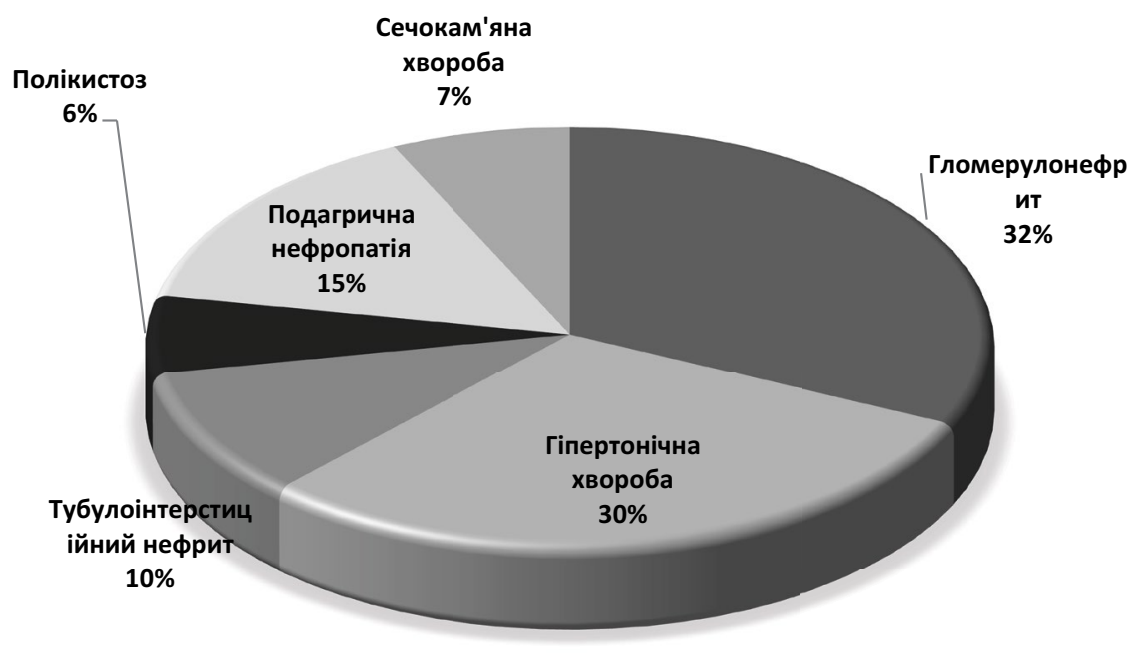

Рис. 1. Розподіл обстежених хворих на ХХН 5Д ст. за нозологіями.

Аналіз МФЕ пацієнтів на гемодіалізі в залежності від його рівня в слині дав змогу розподілити хворих на II групи. До I група увійшли пацієнти з порушеною МФЕ - 84,6\% (n=110) па- цієнтів. II групу склали пацієнти з нормальною MФE (n=20) (табл. 1). Отримані дані свідчать про значну поширеність МФЕ у хворих на гемодіалізі.

Циркадні ритми мелатоніну у групах обстежених

\begin{tabular}{|c|c|c|c|c|c|}
\hline $\begin{array}{c}\text { Час } \\
\text { доби }\end{array}$ & $\begin{array}{c}\text { Референтні } \\
\text { значення }\end{array}$ & $\begin{array}{c}\text { Усі пацієнти на XXH } \\
\text { 5Дст. }(\mathbf{n}=\mathbf{1 3 0})\end{array}$ & $\begin{array}{c}\text { II група, } \\
\text { (n= 20) }\end{array}$ & $\begin{array}{c}\text { I група, } \\
\text { (n=110) }\end{array}$ & P 1-2 \\
\hline День & $<4,9$ пг/мл & $1,9[1,5 ; 2,9]$ & $3,1[2,6 ; 3,5]$ & $1,8[1,5 ; 2,5]$ & $<0,001$ \\
\hline Нічь & $52,3-149$ пг/мл & $20,1[18,2 ; 37,5]$ & $109,3[91,4 ; 130,1]$ & $19,5[17,8 ; 29,7]$ & $<0,001$ \\
\hline
\end{tabular}

За добовим профілем мелатоніну виявлено, що хворі основної групи $(\mathrm{n}=110)$ порівняно з хворими групи II (група порівняння) мають нижчий рівень, як нічного (на 82,2\%, p < 0,05), так і денного (на $43 \%, \mathrm{p}<0,05)$ рівнів.
Аналіз результату дослідження ліпідного метаболізму показав наявність підвищеної концентрації загального холестерину (3X) та всіх його фракцій у пацієнтів на XXН 5 Д ст., що продемонстровано в таблиці 2.

Показники ліпідного спектру крові обстежуваних груп

\begin{tabular}{|c|c|c|c|c|}
\hline Показник & Всі хворі на ГД (n=130) & II група, $\quad \mathbf{( n = 2 0 )}$ & I група, $\mathbf{( n = 1 1 0 )}$ & P1-2 \\
\hline ЗХ & $4,31[2,93 ; 5,62]$ & $3,37[2,37 ; 5,26]$ & $4,4[3,1 ; 5,7]$ & $<0,05$ \\
\hline ТГ & $1,52[1,24 ; 1,77]$ & $1,3[1,2 ; 1,4]$ & $1,55[1,25 ; 1,8]$ & $<0,05$ \\
\hline ЛПНЩ & $1,61[1,25 ; 2,25]$ & $1,27[1,14 ; 1,82]$ & $1,64[1,27 ; 2,26]$ & 0,03 \\
\hline ЛПВЩ & $0,92[0,8 ; 1,45]$ & $1,02[0,94 ; 1,52]$ & $0,9[0,79 ; 1,44]$ & 0,03 \\
\hline КА & $3,14[1,61 ; 5,57]$ & $2,04[1,38 ; 3,17]$ & $3,49[1,72 ; 5,77]$ & 0,01 \\
\hline
\end{tabular}


Під час аналізу результатів серед загальної групи пацієнтів із ХХН 5Д ст. підвищений 3 Х спостерігається у 54\%, з яких на основну групу припадає 89\%. Гіпертригліцеридемія виявляється у $51 \%$ пацієнтів, з яких $94 \%$ складає основна група. Підвищений рівень ліпопротеїдів низької щільності (ЛПНЩ) - у 58\% обстежених, з яких переважна більшість (92\%) це пацієнти з порушеною МФЕ. Високий рівень коефіцієнту атерогенності (КА) визначається у $52 \%$, з яких частка основної групи складала 91\%. Наші дані збігаються з результатами інших досліджень, де поширеність дисліпідемії у пацієнтів на ЗНТ варіює від 20 до 50\% [6]. Однак цікавим $€$ той факт, що більшість когорти пацієнтів з ліпідними порушен- нями склали пацієнти з порушеною МФЕ. Наші результати показали асоціацію порушення МФЕ з ліпідним обміном у хворих на ЗНТ.

Аналіз рівня ліпопротеїдів високої щільності (ЛПВЩ), що володіють антиатерогенними властивостями, показує їх зниження у пацієнтів 3 порушеною МФЕ (на $31 \%$ нижче, ніж у хворих II групи), що може свідчити про більш високий ризик розвитку та прогресування атеросклерозу та серцево-судинних захворювань. Поширеність порушення ліпідного обміну основної групи та групи порівняння представлені на рис. 2. Проте найбільш суттєва різниця між групами стосується рівня ЛПНЩ, яка сягала 33\% з превалюванням у хворих з порушенням МФЕ.

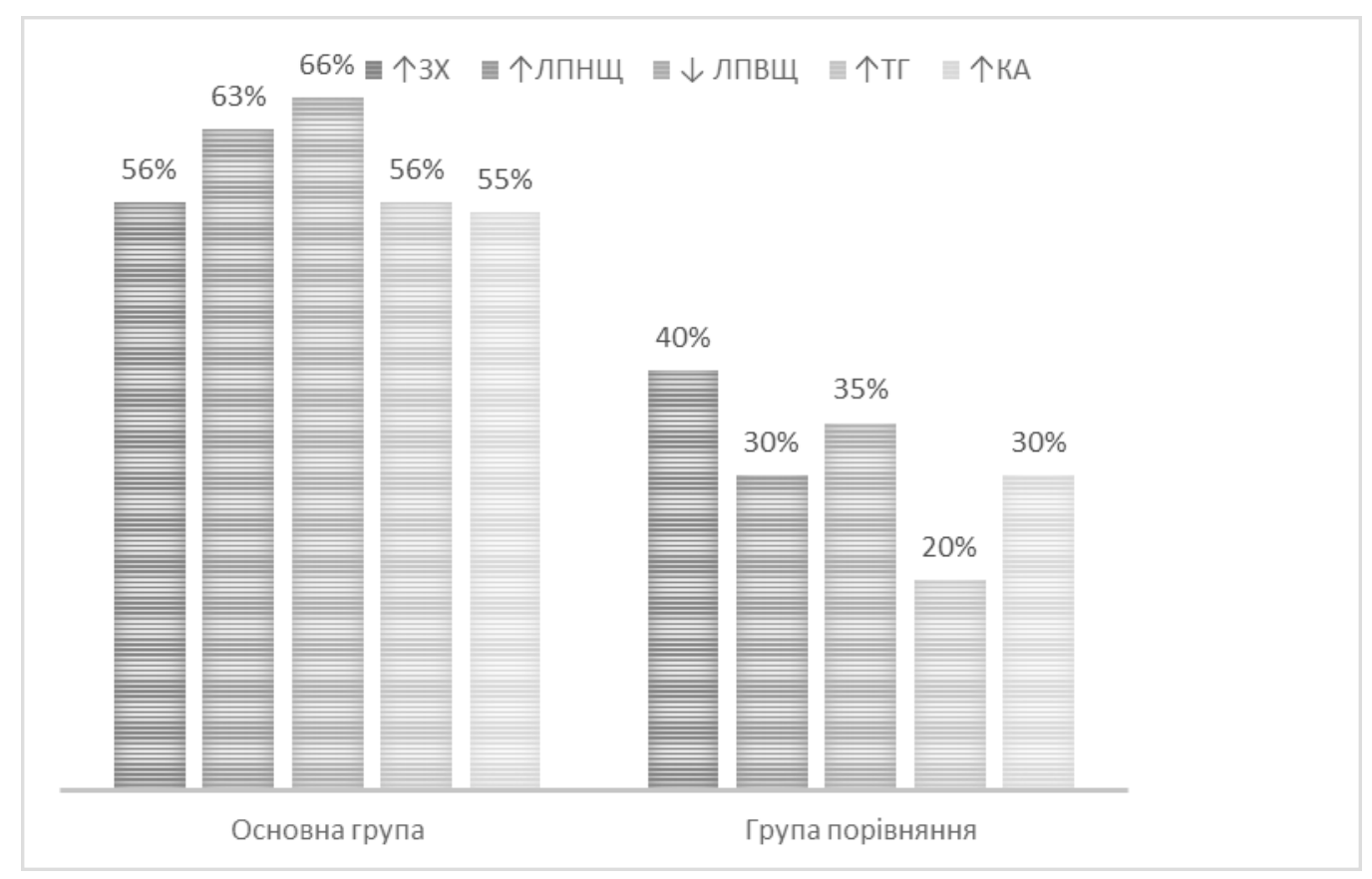

Рис. 2. Ліпідний спектр крові хворих на ХХН 5Дст. залежно від МФЕ

Аналіз взаємозв'язку МФЕ з ліпідним спектром крові виявив негативний кореляційний зв'язок нічного рівня мелатоніну з $3 X(r=-0,26$; $\mathrm{p}<0,05)$ та тригліцеридами (ТГ) $(r=-0,27$; $p<0,05)$, що може свідчити про формування гіперхолестеринемії та гіпертригліцеридемії у разі зниження синтезу мелатоніну. Отримані дані підтверджуються дослідженнями проведеними на щурах, які демонструють наростання рівнів ТГ та 3Х після пінеалектомії [7].

Разом з цим виявлені негативні кореляційні зв'язки між рівнем ТГ і гемоглобіну $(r=-0,20 ; p$ $<0,05)$ та позитивний зв'язок з тривалістю артеріальної гіпертензії $(r=0,24 ; p<0,05)$ і стажем ЗНТ $(r=0,19 ; p<0,05)$. Це свідчить про зростання ступеня дисліпідемії при збільшенні тривалості основної патології та лікування гемодіалізом.
Виявлено негативні кореляційні зв'язки ЛПВЩ з індексом маси тіла пацієнтів ( $r=-0,25 ; p$ $<0,05)$, САТ $(r=-0,3 ; p<0,05)$ та ДАТ $(r=-0,31 ; p$ $<0,05)$. Спостерігався позитивний кореляційний зв'язок ЛПВЩ з нічним $(r=0,33 ; p<0,05)$ та денним рівнем мелатоніну $(r=0,27 ; p<0,05)$ та гемоглобіном $(r=0,21 ; p<0,05)$. Взаємозв'язок ЛПВЩ та МФЕ може пояснюватися наявністю важливого компоненту ЛПВЩ - параоксонази, ферменту, який пригнічує окислення ЛПНЩ. Активність даного ферменту у хворих на XXН може значно зменшуватися та сприяти процесам окислення ЛПНЩ. Мелатонін запобігає останнім, тому зниження синтезу мелатоніну може бути пов'язане зі зменшенням рівня ЛПВЩ, що спостерігається і в нашій роботі [8]. 


\section{Висновки:}

1. Для хворих на хронічну хворобу нирок, що лікуються методами нирково-замісної терапії, характерне значне порушення МФЕ (84,6\%).

2. Хворі на ХХH 5Д стадії демонструють значні порушення ліпідного обміну: збільшення концентрації атерогенних фракцій (до 58\%) і зниження антиатерогенних (до 62\%).

3. У хворих на НЗТ характер дисліпідемії пов'язаний з порушенням мелатонінутворювальної функції епіфізу: найбільше зниження синтезу мелатоніну виявляється при зростанні ЛПНЩ і зниженні ЛПВЩ, що потребує корекції з метою поліпшення прогнозу.

Слід зазначити, що зміни ліпідного спектру крові у хворих на ХХН 5Д стадії на тлі прийому мелатоніну $€$ предметом подальших досліджень та будуть представлені у наступних повідомленнях.

\section{ЛITEPATУРA}

1. Alonso-Gonzalez, C., Gonzalez, A., MartinezCampa, C., Menendez-Menendez, J., GomezArozamena, J., \& Garcia-Vidal, A. et al. Melatonin enhancement of the radiosensitivity of human breast cancer cells is associated with the modulation of proteins involved in estrogen biosynthesis// Cancer Letters. - 2016. - Vol. 370. - P. 145-152.

2. Anwar M. J., Muhammad B. Y., Bader A. A., Abdulghani, M., Mahmood, D., \& Haider, M. An insight into the scientific background and future perspectives for the potential uses of melatonin// Egyptian Journal of Basic and Applied Sciences. - 2015. - Vol. 2. - P. 139-152.

3. Jardine A. G., SchmiederR. E. et al. Rosuvastatin and cardiovascular events in patients undergoing hemodialysis// N. Engl. J. Med. - 2009. - Vol. 360 (14). - P. 1395-1407

4. Keane WF, Tomassini JE, Neff DR. Lipid abnormalities in patients with chronic kidney disease: implications for the pathophysiology of atherosclerosis// J. Atheroscler Thromb. - 2013. - Vol. 20(2). - P. 123-133.

5. KGIGO Clinical Practice Guideline for Lipid Management in Chronic Kidney DiseaseKidney// International supplements. - 2013. - Vol. 3.

6. Mohammed I.N., Alwahami A.A. Dyslipidemia in chronic renal failure// Muthanna Medical Journal. - 2018. - Vol. 5(2). - P. 66-85.

7. Slawik H., Stoffel M., RiedI L. Prospective Study on Salivary Evening Melatonin and Sleep before and after Pinealectomy in Humans// J. Biological Rhythms. - 2016; Vol. 31(1). - P. 82-93.
8. Sun H, Huang F-f, Qu S. Melatonin: a potential intervention for hepatic steatosis// Lipids Health Dis. - 2015. Vol. 14(1). - P. 75.

9. Сериков В.С., Ляшев Ю.Д. Влияние мелатонина на изменения липидного обменя при имобилизацинном стрессе// Курский научнопрактический вестник «Человек и его здоровье». - 2016. - № 2. - С. 81-84.

10. Смирнов А.В., Добронравов В.А., Каюков И.Г. Эпидемиология и социально-экономические аспекты хронической болезни почек// Нефрология. - 2006. - Т.10, № 1. - С. 7-13.

\section{PЕЗЮMЕ}

\section{ОСОБЕННОСТИ МЕЛАТОНИНОБРАЗОВАТЕЛЬНОЙ ФУНКЦИЯ ЭПИФИЗА И ДИСЛИПИДЕМИИ У БОЛЬНЫХ ХРОНИЧЕСКОЙ БОЛЕЗНЬЮ ПОЧЕК 5 Д СТАДИИ}

Кондратюк В.Е., Петрова А.С., Карпенко Е.В., Григорьева Е.M.

\section{(Киев)}

Цель исследования: проанализировать липидный спектр крови больных хронической болезнью почек (ХБП) 5Д стадии и определить взаимосвязь дислипидемии с мелатонинобразовательной функцией эпифиза (МФЭ).

Материал и методы: Обследовано 130 человек (пол. м, n - 65) в возрасте 58,5 [43; 66] лет, которые находятся на постоянном лечении гемодиализом. Всех больных обследовали лабораторно - взят общий и биохимический анализы крови, определенна липидограмма, дневной и ночной уровень мелатонина в слюне, проведено измерение офисного артериального давления.

Результаты и обсуждение: Определенна значительная распространенность нарушений МФЭ у больных на гемодиализе и его взаимосвязь с липидным спектром крови. Определена отрицательная корреляционная связь ночного уровня мелатонина с общим холестерином ( $r=-0,26 ; p<0,05)$, отрицательная корреляционная связь с триглицеридами $(r=-0,27 ; p$ $<0,05)$, положительная корреляционная связь с липопротеидами высокой плотности и МФЭ ( $r=0,33 ; p$ $<0,05)$. При анализе результатов исследования липидного метаболизма у пациентов на гемодиализе отмечено наличие повышенной концентрации общего холестерин (ОХ), триглицеридов (ТГ), фракций липопротеидов низкой плотности (ЛПНП) и низкое содержание липопротеидов высокой плотности (ЛПВП). Больные с нарушенной МФЕ по сравнению с группой II имеют достоверно высшие уровни ОХ, ТГ, ЛПНП и более низкие уровни ЛПВП.

Выводы: для больных на ХБП 5Д стадии, которые лечатся методом гемодиализа, присущие выраженные нарушения липидного обмена (58\%). У больных на почечно - заместительной терапии нарушения липидного метаболизма ассоциировано с мелатонинобразовательной функцией эпифиза, уровнями систолического и диастолического артериального давления, продол- 
жительностью артериальной гипертензии, уровнем гемоглобина и продолжительностью лечения гемодиализа.

Ключевые слова: хроническая болезнь почек, гемодиализ, мелатонин, мелатонинобразовательная функция эпифиза, дислипидемия.

\section{SUMMARY}

FEATURES OF MELATONINE-FORMING FUNCTION OF EPIPHYSIS AND DYSLIPIDEMIA IN PATIENTS WITH CHRONIC KIDNEY DISEASE 5 D STAGE

Kondratiuk V.E., Petrova A.S., Karpenko E.V., Grigoryeva E.M.

(Kyiv)

Objective: to analyze the blood lipid spectrum of patients with chronic kidney disease (CKD) 5D stage and to determine the relationship of dyslipidemia with melatoninforming function of the pineal gland (MFE).

Material and methods: 130 people (gender, $m-65$ ) at the age of 58.5 were examined $[43 ; 66]$ years who are on continuous treatment with hemodialysis. All patients were examined in a laboratory - general and biochemical blood tests were taken, a lipid profile was determined, daily and nighttime levels of melatonin in saliva were measured, and office blood pressure was measured.

Results and discussion: A significant prevalence of MFE disorders in hemodialysis patients and its relationship with the blood lipid spectrum were determined. The negative correlation between the night level of melatonin and total cholesterol $(r=-0.26 ; p<0.05)$, the negative cor- relation with triglycerides $(r=-0.27 ; p<0.05)$, the positive correlation with lipoproteins were determined high density and MFE $(r=0.33 ; p<0.05)$. An analysis of the results of a study of lipid metabolism in hemodialysis patients revealed the presence of an increased concentration of total cholesterol, triglycerides, low density lipoprotein fractions and a low content of high density lipoproteins. Patients with impaired MFE have significantly higher levels of total cholesterol, triglycerides, low-density lipoproteins, and lower levels of high-density lipoproteins compared to group II.

Conclusions: For patients with CKD stage 5D treated with the method of hemodialysis, there are pronounced disorders of lipid metabolism (58\%). In patients with renal replacement therapy, disorders of lipid metabolism are associated with melatonin-forming function of the epiphysis, levels of systolic and diastolic blood pressure, duration of hypertension, hemoglobin level, and duration of hemodialysis treatment.

Key words: chronic kidney disease, hemodialysis, melatonin, melatonin-forming function of the pineal gland, dyslipidemia.

\section{Петрова Анна Сергіївна anna2311doc@ukr.net}

